\title{
Development of Socioscientific Issues-Based Teaching Materials to Improve Learning Outcomes and Students' Environment Awareness on The Environmental Changing Material
}

\author{
Dian Muhimmatun Ma’rufah ${ }^{\bowtie}$, Sri Ngabekti, Ning Setiati \\ Pascasarjana, Universitas Negeri Semarang, Indonesia
}

\begin{tabular}{|c|c|}
\hline Article Info & Abstract \\
\hline $\begin{array}{l}\text { Article History : } \\
\text { Received June } 2020 \\
\text { Accepted July } 2020 \\
\text { Published April } 2021\end{array}$ & \multirow{3}{*}{$\begin{array}{l}\text { Environmental problems can't be avoided in big cities including Semarang city. } \\
\text { This needs to be raised in learning one of them through the development of } \\
\text { teaching materials based on socioscientific issues. The purpose of this study is } \\
\text { to develop teaching materials based on socioscientific issues, test the } \\
\text { effectiveness of teaching materials, analyze students and teacher responses of } \\
\text { teaching materials. This research is a Research \& Development. We develop } \\
\text { teaching materials based on socioscientific issues by utilizing local realities of } \\
\text { Environmental Change in Semarang city. The expert's validation of material } \\
\text { and media was } 87.04 \% \text { and } 97.92 \% \text {. It was categorized in very valid criteria. } \\
\text { Teaching materials developed were effective in increasing students' cognitive } \\
\text { learning outcomes with classical completeness by } 86.36 \% \text { and n-gain test by } \\
0.55 \text {. Students' environmental care attitudes increase with a percentage of } \\
83.33 \% \text { in very caring criteria. The readability response of students and teachers } \\
\text { was } 83.75 \% \text { and } 97.69 \% \text { in very good criteria. The practicality responses of } \\
\text { students and teachers was } 86.25 \% \text { and } 95 \% \text { with very practical criteria. The } \\
\text { conclusion of this study is teaching material developed are effective for } \\
\text { improving cognitive learning outcomes and students' environmental care } \\
\text { attitudes. The response of students and teachers in readability is very good, the } \\
\text { response of students and teachers in practicality is very practical. }\end{array}$} \\
\hline $\begin{array}{l}\text { Keywords: } \\
\text { Socioscientific Issues, } \\
\text { learning outcomes, } \\
\text { students' environmental } \\
\text { care attitudes }\end{array}$ & \\
\hline & \\
\hline
\end{tabular}

correspondence:

Pascasarjana, Universitas Negeri Semarang, Indonesia

Jalan Kelud Utara III No. 37, Semarang, Jawa Tengah,

p-ISSN 2252-6412

Indonesia 50237

E-mail: dian.muhimmatun@gmail.com 


\section{INTRODUCTION}

Semarang is one of the major cities in Indonesia and the capital of the Province of Central Java. As a big city, various environmental problems can't be avoided from this city. Semarang located in a coastal area, is one of the areas prone to flooding or tidal flooding. All environmental problems that occur Semarang need to be raised in learning at school so that students are expected to better understand the real conditions that exist in their environment.

The contextual aspect is needed in learning the environment, that environmental issues are closely related to daily life which does not merely involve knowledge but requires attitudes and skills to resolve these problems. Therefore, learning should be designed and implemented through strategies to meet these contextual needs, one of them is by learning to use socio-scientific issues (Socioscientific issues learning) (Subiantoro et al., 2013). Socioscientific issues (SSI) are strategies that aim to stimulate intellectual, moral and ethical development, and awareness about the relationship between science and social life (Zeidler et al., 2005). Socio-scientific issues are issues that describe the social problems of society that are related to a conceptual, procedural, or technological context to science (Sadler \& Ziedler, 2004).

Based on observations with Biology teachers at SMA Setiabudhi Semarang, learning activities are still dominated by teachers using the lecture method and are still teacher-centered. Learning still uses textbooks that are general and do not lead to the use of local realities around the students' environment. The reason teachers haven't utilized local reality in learning because Biology learning time is very limited while the material taught must be a lot.

The learning process that doesn't utilize the local reality of the surrounding environment as a source of learning makes students not actively involved in learning. This learning process causes learning in the classroom to not run optimally because students tend to memorize theories and haven't linked them with the surrounding environment. This is the cause of the low student learning outcomes with the large number of students who have not yet reached the KKM (Minimum Completeness Criteria) $\geq 65$ and students' environmental care attitudes are still low. The low students' environmental care attitudes are shown by the lack of students' sensitivity to environmental problems that occur around them, cleanliness of the classroom that has not been maintained, and lack of awareness to dispose of garbage.

Socio-scientific issues learning by raising local realities need to be supported by appropriate teaching materials. The development of teaching materials based on the study of local reality provides an alternative contextual learning source, according to students' environmental conditions so that it will add to the student's learning experience. The existence of teaching materials that raise local reality, it is expected that learning outcomes and student's environmental care attitudes will increase. Djulia (2005) states that raising local realities in learning will increase students' understanding of the material and increase their concern for the environment and can enrich learning material.

The purpose of this research is to develop instructional materials based on socioscientific issues, test the effectiveness of instructional materials based on socioscientific issues in terms of learning outcomes and students' environmental care attitudes, analyzing student and teacher responses to the development of socioscientific issues-based teaching materials.

\section{METHODS}

This research used the research and development (R\&D) method with Sugiyono's development model (2015). The first stage in developing teaching materials is analyzing the needs of students in developing teaching materials through questionnaires for student needs and interviews with Biology teachers. The next step is to develop teaching material products. Teaching materials developed were then validated by material experts and media experts, the results were used to revise the lack of teaching materials. The next stage was a trial of teaching materials on a limited scale to teachers and 10 students of grade XI MIPA as respondents through a readability test using a questionnaire. Results from limited scale trials are used to improve teaching materials. The improved teaching material was then tested for effectiveness on students' cognitive learning outcomes through the One Group Pretest-Posttest Design research design to 22 students of grade X MIPA SMA (Senior Hight 
School) Setiabudhi Semarang in the 2019/2020 school year. The effectiveness test of teaching materials was also carried out towards students' environmental care attitudes through questionnaires. After learning is completed, a practical questionnaire is given to teaching materials and students.

\section{RESULTS AND DISCUSSION}

\section{Analysis of Student Needs}

Analysis of student needs aims to determine whether or not teaching materials to be developed. Based on a questionnaire distributed to 10 students grade $\mathrm{X}$ of SMA Setiabudhi randomly, as many as $74.33 \%$ of students agreed to the development of teaching materials based on socioscientific issues on environmental change by raising local reality. Students state that the teacher has never developed teaching materials that are adapted to the conditions of the surrounding environment. Therefore, students state the need for teachers to develop teaching materials that are adapted to the environmental conditions around students. This is consistent with the study of Jayanti et al. (2017), which states that students consider it important and need to learn and integrate the local potential and local wisdom in biology learning.

Based on the results of the biology teacher interview about the condition of learning activities in SMA Setiabudhi Semarang, the biology learning activities that have been carried out are quite good. However, learning seems monotonous and less varied, one of the causes is the lack of variation in the learning resources used. In learning environmental change material, the material presented is still general that refers to textbooks, the teacher has not utilized local realities that occur around students to be appointed in learning. Therefore, if teaching materials can be developed by raising local realities it will be very interesting and help students in learning biology. This is consistent with the opinion of Susilo (2018) which states that in most schools, they have not utilized the natural environment as a source of learning in their learning, especially the potential of learning resources in their respective regions. The utilization of materials and local-based learning media is still limited to the school environment and has not utilized local potential.

\section{Teaching Material Validation}

The teaching material that has been developed is then assessed by the material experts and the media experts. This is done to find out that teaching materials already meet the minimum validity required so that they can be used in learning. The results of the validation of material experts and media experts can be seen in Table 1 .

Table 1. Assessment of the Validation of Teaching Materials

\begin{tabular}{lll}
\hline Assessment aspects & $\begin{array}{l}\text { Percentage } \\
(\%)\end{array}$ & Criteria \\
\hline Material experts & & \\
\hline Feasibility of contents & 90.28 & Very valid \\
$\begin{array}{l}\text { Presentation } \\
\text { Linguistic }\end{array}$ & 91.67 & Very valid \\
\hline Average & 79.17 & Valid \\
\hline Media experts & 87.04 & Very valid \\
\hline $\begin{array}{l}\text { Size of teaching material } \\
\text { Cover design }\end{array}$ & 100 & Very valid \\
$\begin{array}{l}\text { Content design } \\
\text { Use of letters }\end{array}$ & 100 & Very valid \\
$\begin{array}{l}\text { Presentation technique } \\
\text { Supporting presentation } \\
\text { of material }\end{array}$ & 91.67 & Very valid \\
$\begin{array}{l}\text { Completeness of } \\
\text { presentation }\end{array}$ & 100 & Very valid \\
\hline Average & & Very valid \\
\hline
\end{tabular}

Based on Table 1., the average percentage score of the validity of teaching materials by material experts is $87.04 \%$ with very valid criteria. Teaching material developed is suitable for use in learning based on the feasibility of the material/content, presentation, and language. The teaching material developed has been following $\mathrm{KI}, \mathrm{KD}$, and learning objectives. Teaching materials developed are also based on local realities that occur around students, so students can link learning material with the local reality of the environment around students. Rahayu and Sudarmiatin (2010) stated the module was said to be suitable for use in learning if it was effective in achieving certain competencies, the systematic writing of the module was easy to understand, the module material was relevant to the competency measured and the reference used was up to date.

Based on Table 1, the average percentage score of the validity of teaching materials by media experts is $97.92 \%$ with very valid criteria. This is because the size of teaching materials has met ISO 
standards, the design of the cover and overall appearance is attractive, the use of types and sizes of letters that are precise and easy to read, photos and illustrations that are displayed clearly and following the material presented, systematic in the appropriate teaching materials, and supporting the presentation of complete teaching materials. This is following the opinion of Mardiani \& Noerhodijah (2015) stating that the design of the module display is attractive, the design of the cover illustrates the contents of the material, uses letters that are easy to read, and the systematic sequence of material will make students interested in learning the module. Wulandari et al. (2017) states the presentation of teaching material supplements prepared with supporting the presentation of the complete material will be interesting for students.

\section{Readability of Teaching Materials}

Yuliana (2012) states that the readability test of teaching materials aims to identify errors that exist in teaching materials, identify words that are difficult to understand, and identify the user's reaction when reading them. The results of the readability assessment of teaching materials by students and teachers can be seen in Table 2 .

Table 2. Assessment of Readability of Teaching Materials

\begin{tabular}{lll}
\hline Readability & Percentage (\%) & Criteria \\
\hline Students & 83,75 & Very good \\
Teacher & 97,69 & Very good \\
\hline
\end{tabular}

Based on Table 2., the average percentage of students' readability was $83.75 \%$ with very good readability criteria. Students state the letters used in teaching materials are clear, the size of the letters is right, making it easier for students to read the teaching material. Students state the cover design, pictures, illustrations, color composition presented in teaching materials look interesting and harmonious, this makes students interested in learning teaching materials. Leksono (2015) states that the display of illustrations clearly and interestingly will increase students' motivation to learn teaching materials. The existence of illustrations in teaching materials will also facilitate the understanding of students.

Students can understand and comprehend the contents of teaching materials. This is because the sentence structure and language used in teaching materials are clear, effective, communicative, and easy to understand. The description of the material presented in the teaching material is clear and detailed to cause students not to feel confused. Following research by Nuraini et al. (2014) that teaching materials are easy to understand because the language delivered is quite communicative and the terms used are appropriate to the age of the student.

Based on Table 2., the average readability of teachers is $97.69 \%$ with very good criteria. The readability assessment aspects of the teacher include aspects of content worthiness, linguistics, and presentation. According to the teacher, the material contained in teaching materials is developed following $\mathrm{KI}, \mathrm{KD}$, and learning objectives. The material presented in teaching materials is following the latest / up-to-date and contextual nature. This is by the opinion of Asfiah and Purwantoyo (2013) that the description of the material and examples in teaching materials should be adjusted to the closest environmental conditions that are often encountered in daily life so that students can associate the material learned with real life.

The language used in teaching materials is effective, communicative, and can be easily understood by teachers and students. Presentation, picture/illustration, writing, and appearance of teaching materials are categorized as very good and interesting. Hasanah et al. (2016) states that teaching materials that are presented in communicative language will make it easier for students to understand the material in teaching materials, in addition to that teaching materials that are accompanied by a variety of colorful and interesting images can make students interested in learning.

\section{The Effectiveness of Teaching Materials Student cognitive learning outcomes}

This study applies learning activities by using socioscientific issues teaching materials on environmental changes in grade X. Pretest is done before learning activities. The teacher provides learning material using socioscientific issues teaching material. After completing the study, a posttest was conducted. The results of the pretest and posttest were analyzed to determine the results of students' mastery learning. The results of the pretest and posttest were also analyzed using the $\mathrm{N}$-gain test. The $\mathrm{N}$-gain value shows the influence of socioscientific issues-based teaching materials in 
improving student cognitive learning outcomes. Data mastery learning students and gain normality test can be seen in Tables 3 and 4 .

Table 3. Data Completeness Student Learning Outcomes

\begin{tabular}{ccccccc}
\hline$\sum$ & $\sum$ & $\sum$ & \multicolumn{2}{c}{ Final score } & Average & $\begin{array}{c}\text { Classical } \\
\text { completeness } \\
\text { Students }\end{array}$ \\
\cline { 4 - 6 } & $\begin{array}{c}\text { Completed } \\
\text { students }\end{array}$ & $\begin{array}{c}\text { Incompleted } \\
\text { students }\end{array}$ & Highest & Lowest & & \\
\hline 22 & 19 & 3 & 88 & 70 & 80,15 & 86,36 \\
\hline
\end{tabular}

Based on Table 3, the classical completeness of student learning outcomes is $86.36 \%$ with an average value of 80.15 . Of the 22 students, 19 students were declared complete and 3 students declared incomplete. The highest final score of students is 88 and the lowest final grade of students is 70 . This shows that the application of teaching materials based on socioscientific issues material changes in an effective environment based on the results of classical completeness obtained by students.

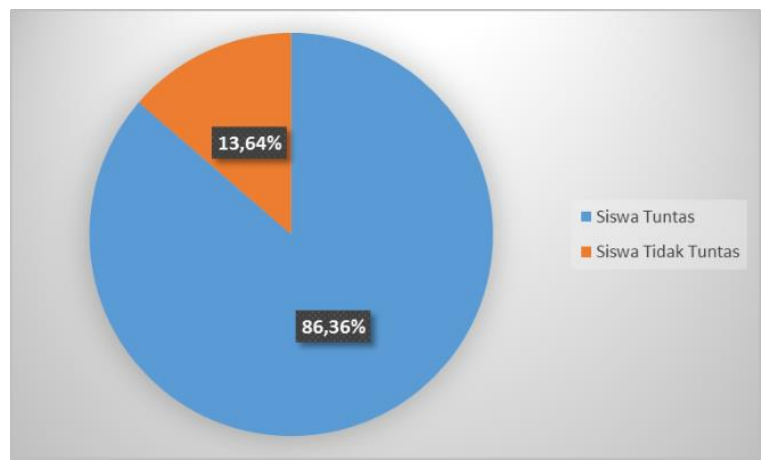

Figure 1. Classical Completeness of Student Learning Outcomes

Based on Figure 1, students who didn't complete as many as 3 students with a percentage of $13.64 \%$. Student incompleteness is caused by many factors, including students' lack of readiness to receive lessons, lack of student motivation, lack of student understanding of learning material, to students less like biology subjects. This is following Effendi's research (2017), that the readiness of learning makes students motivated to optimize their learning outcomes.

Table 4. Gain Normality Test

\begin{tabular}{llll}
\hline Data & $\begin{array}{l}\text { Pretest } \\
\text { score }\end{array}$ & $\begin{array}{l}\text { Posttest } \\
\text { score }\end{array}$ & N-gain \\
\hline Highest score & 25 & 28 & 0,78 \\
Lowest score & 19 & 23 & 0,22 \\
Average & & & 0,55 \\
Criteria & & & Moderate
\end{tabular}

Based on Table 4., the mean normality gain ( $\mathrm{N}$-gain) of 0.55 with moderate criteria. The highest $\mathrm{N}$-gain is 0.78 (high criterion) while the lowest $\mathrm{N}$ gain is 0.22 (low criterion). This shows that there is an influence between teaching materials based on socioscientific issues with an increase in students' cognitive learning outcomes in SMA Setiabudhi. Kartuti et al., (2016) stated that the increase in student learning outcomes from the pretest and posttest because the learning activities carried out provide a contextual atmosphere to increase student interest in learning.

Development of socioscientific issues teaching materials on environmental change material that raises local realities of environmental problems such as flooding and rob and environmental pollution that occurs around students is effective to improve student learning outcomes. This is because the material presented is very close to student life. Students can link the theoretical concepts learned about environmental change with the events of daily life experienced by students. Learning by using this teaching material requires students to be actively involved in discussions and presentations with other students to arouse students' enthusiasm in learning activities and make the classroom atmosphere more active and enjoyable. This is following Stolz et al. (2013) which states that learning socioscientific issues can increase motivation and enhance students' ability to evaluate controversial issues to shape student attitudes towards a better direction. Presley et al. (2013) added that one of the successes of learning socioscientific issues is the teacher's role in facilitating students in discussion, argumentation, reasoning, and decision making.

\section{Students' environmental care attitudes}

Assessment of students 'caring attitudes is done by distributing questionnaires to students' environmental care attitudes after learning is complete. The results of the percentage of students' environmental care attitudes in this study amounted to $83.33 \%$ with the criteria of very caring. Susani et al. (2019) states that students' knowledge of the environment will have a positive influence on increasing environmental attitudes and awareness in students. Hebel et al. (2014) added that students with a high level of awareness of environmental problems and high motivation in protecting the environment 
will also have a high attitude in environmental preservation efforts.

Learning biology by using teaching materials socioscientific issues material environmental changes that raise local realities can improve students' environmental care attitudes. Following the opinion of Darner (2014), learning socioscientific issues can make students involved in investigating environmental issues, attracting students to take concrete actions to the environment arising from selfawareness.

The lowest percentage of students' environmental care questionnaire was found in the question items about the use of public transportation. Some students choose to ride public transportation when going to school or traveling for comfortable reasons, and some students can't ride a private vehicle so choose to ride public transportation. But some of them choose to use their vehicles with the reason to save more costs, the time required is shorter than riding public transportation, and there is no route of destination.

The highest percentage is in the question items about students reprimanding other students who are polluting, inviting students to maintain cleanliness, and protect the environment. According to students, a clean environment makes students comfortable in carrying out any activity, and protecting the environment is the responsibility of students. The question got the highest score because it is a criterion for environmental care attitude that is often done continuously so that it has become a habit and character for students. In the opinion of Hazami et al. (2015), that the attitude of caring for the environment if done continuously will shape the character so that it will bring up the attitude of responsibility of students in protecting and caring for the environment.

Utilizing local reality as a learning resource makes students more familiar with the conditions of their environment so students will have an awareness of their role in protecting and protecting the preservation of the surrounding environment. Following the opinion of Sujarwo et al., (2015), the implementation of environmental education based on local potential is directed at efforts to foster students' awareness of knowledge, skills, and experience in utilizing their potential.

\section{Practicality of Teaching Materials}

The practicality of teaching materials is measured by the questionnaire the practicality of teaching materials by students and teachers after learning is finished. Alfiriani \& Hutabri (2017) states that practicality refers to teaching materials developed that are easy to use by users in this case teachers and students so that learning will be more meaningful, interesting, enjoyable, and useful for students' lives, and can increase student creativity in learning activities. Data on the practicality of teaching materials can be seen in Table 5 .

Table 5. Assessment of Practicality of Teaching Materials

\begin{tabular}{lll}
\hline Practicality & Percentage (\%) & Criteria \\
\hline Students & 86.25 & Very practical \\
Teacher & 95 & Very practical \\
\hline
\end{tabular}

Based on Table 5, the average practicality of students is $86.25 \%$ with very practical criteria. Most of the students gave positive comments, which felt helped by the presence of teaching materials. According to students, interesting teaching materials to learn, motivate students to be active in discussion and presentation activities in learning and inspire students to care about the environment.

Based on Table 5, the average practicality of teachers on teaching materials is $95 \%$ with very practical criteria. According to the teacher teaching materials facilitate students and teachers in understanding learning material. Socio-scientific issues raised in teaching materials on environmental change are issues that are close to daily life so students will gain factual knowledge. Discussions on sociocultural issues can construct students' knowledge about local realities that occur around students. The teacher also states that teaching materials are very practical, easy to use, easy to carry, and safe to use in learning.

Teaching materials based on socioscientific issues material on environmental changes that raise local reality are very practical to use in learning activities. Following the opinion of Novera et al. (2019), that modules developed based on local potential can facilitate the teacher in delivering subject matter and make it easier for students to understand the subject matter, students can analyze problems around the student environment, students can relate the theory learned to everyday events, and 
can direct students to utilize learning resources in the surrounding environment.

\section{CONCLUSION}

Based on the description above it can be concluded that the development of teaching materials based on socioscientific issues of environmental change material that utilizes local realities of environmental change in Semarang following the research and development (R\&D) method of Sugiyono's development model. Effective teaching materials to improve cognitive learning outcomes and attitudes to care for the student's environment. The response of students and teachers in terms of readability is very good, and the response of students and teachers in terms of practicality is very practical.

\section{REFERENCES}

Alfiriani, A., \& Hutabri, E. 2017. Kepraktisan dan keefektifan modul pembelajaran bilingual berbasis komputer. Jurnal Kependidikan, 1 (1), 12-23.

Asfiah, N., \& Purwantoyo, E. 2013. Pengembangan modul IPA terpadu kontekstual pada tema bunyi. Unnes Science Education Journal, 2 (1): 188-195.

Darner, R. 2014. Influences on students' environmental self-determination and implications for science curricula. International Journal of Environmental \& Science Education, 9 (1), 21-39.

Djulia, E. 2005. Peran Budaya Lokal dalam Pembentukan Sains (Studi Naturalistik Sains Siswa Kelompok Budaya Sunda tentang Fotosintesis dan Respirasi Tumbuhan dalam Konteks Sekolah dan Lingkungan Pertanian. Disertasi. Sekolah Pascasarjana, Universitas Pendidikan Indonesia, Bandung.

Effendi. 2017. Hubungan readiness (kesiapan) belajar siswa dengan hasil belajar fisika siswa kelas $\mathrm{X}$ SMK Muhammadiyah 03 Sukaraja. Jurnal Pendidikan Fisika, 5 (1), 15-24.

Hasanah, I., S. Wahyuni, dan R. W. Bachtiar. 2016. Pengembangan modul mitigasi bencana berbasis potensi lokal yang terintegrasi dalam pelajaran IPA di SMP. Jurnal Pembelajaran Fisika, 5 (3), 226-234.

Hazami, Ridlo, S., \& Iswari, R. S. 2015. Pengembangan perangkat pembelajaran berorientasi pendidikan sikap peduli lingkungan dengan metode hypnoteaching pada materi pencemaran. Journal of Innovative Science Education, 4 (2), 76-82.

Hebel, F. L., Montpied, P., \& Fontanieu, V. 2014. What can influence students' environmental attitudes?
Results from a study of 15-year-old students in France. International Journal of Environmental \& Science Education, 9, 329-345.

Jayanti, U. N. A. D., Herawati, S., \& Endang, S. 2017. Analisis kebutuhan bentuk sumber belajar dan media pembelajaran biologi berbasis potensi lokal untuk kelas X SMA di Provinsi Lampung. Pros. Seminar Pend. IPA Pascasarjana UM, Vol (2), 591599.

Kartuti, Ngabekti, S., \& Retnoningsih, A. 2016. Pengembangan perangkat pembelajaran keanekaragaman hayati dengan memanfaatkan ekosistem mangrove sebagai sumber belajar di SMA. Unnes Science Education Journal, 5 (1), 10851090.

Leksono, S. M., Syachruroji. A., \& Pipit, M. 2015. Pengembangan bahan ajar biologi konservasi berbasis etnopedagogi. Jurnal Kependidikan, 45 (2), 168-183.

Mardiani, E., \& Noerhodijah, S. R. 2015. Penyusunan modul pembelajaran jaringan tumbuhan berbasis hakikat sains. Jurnal Biodidaktika, 10 (2), 1-5.

Novera, D., Indriyanti, D. R., \& Marianti, A. 2019. The development of ecosystem module based on science literacy in senior high school. Journal of Innovative Science Education, 8 (3), 271 - 278.

Nuraini, N. F., Ridlo, S., \& Susilowati, S. M. E. 2014. Pengembangan modul pendidikan lingkungan hidup (PLH) berbasis karakter untuk menumbuhkan wawasan dan karakter peduli lingkungan. Unnes Journal of Biology Education, 3 (1), 53-60.

Presley M. L., Sickel, A. J., Muslu, N., Johnson, D. M., Witzig, S. B., Izci, K., \& Sadler, T. D. 2013. A framework for socio-scientific issues-based education. Science Educator, 22(1), 26-32.

Rahayu, W. P., \& Sudarmiatin. 2010. Pengembangan modul kewirausahaan di SMK. Jurnal Ilmu Pendidikan, 17 (2), 157-161.

Sadler, T. D., \& Zeidler, D. L. 2004. The morality of socioscientific issues: construal and resolution of genetic engineering dilemmas. Science Education, 88 (1), 4-27.

Stolz, M., Witteck, T., Marks, R., \& Eilks, I. 2013. Reflecting socio-scientific issues for science education coming from the case of curriculum development on doping in chemistry education. Eurasia Journal of Mathematics, Science \& Technology Education, 9 (4), 361-370.

Subiantoro, A. W., Ariyanti, N. A., \& Sulistyo. 2013. Pembelajaran materi ekosistem dengan socioscientific issues dan pengaruhnya terhadap reflective judgment siswa. Jurnal Pendidikan IPA Indonesia, 2 (1), 41-47.

Sugiyono. 2015. Metode Penelitian Kuantitatif, Kualitatif dan $R \& D$. Bandung: Alfabeta. 
Sujarwo, Mulyadi, \& Tohani, E. Model pendidikan sadar lingkungan masyarakat korban erupsi Merapi berbasis potensi lokal. Jurnal Cakrawala Pendidikan, 34 (1), 12-23.

Susani, D, E., Ngabekti, S., \& Priyono, B. 2019. The effect of problem-based learning for environmental change concept on students' learning outcomes. Journal of Biology Education, 8 (1), 8-14.

Susilo, M. J. 2018. Analisis potensi lingkungan sekitar sebagai sumber belajar biologi yang berdayaguna. Proceeding Biology Education Conference, 15 (1), 541 546.
Wulandari, Widiyaningrum, P., \& Setiati, N. 2017. Pengembangan suplemen bahan ajar biologi berbasis riset identifikasi bakteri untuk siswa SMA. Journal of Innovative Science Education, 6 (2), 155161.

Yuliana, E. 2012. Penilaian tingkat keterbacaan materi modul melalui evaluasi formatif. Jurnal Pendidikan Terbuka dan Jarak Jauh, 13 (2), 113-124.

Zeidler, D. L., Sadler, T. D., Simmons, M. L., \& Howes, E. V. 2005. Beyond STS: A research based framework for socioscientific issues education. Journal of Science Education, 89 (3), 357-377. 